\title{
THE INFLUENCE OF THE PLANTATION ESTABLISHMENT METHOD ON THE YIELD OF MARSHMALLOW (ALTHAEA OFFICINALIS L.) FLOWERS
}

\author{
Sylwia Andruszczak \\ Department of Agroecology, University of Life Sciences in Lublin, Akademicka 13, 20-950 Lublin, Poland \\ e-mail: sylwia.andruszczak@up.lublin.pl
}

Received: 8.11.2007

\section{S u m m a r y}

The field experiment with one- and two-year-old marshmallow plants was carried out in Zamość on brown soil of loess origin in 2002-2004. There were four methods of plantation establishment: 1) direct sowing in the field (control object); 2) direct sowing in the field with cover of polypropylene sheet; 3) by seedlings from a plastic house; 4) by seedlings produced in multi-cell propagation trays. It was found that, in the case of one-year-old plants, all the methods of plantation establishment significantly increased the yield and the number of marshmallow flowers, as compared to the control object, but the best results were obtained when the plants were propagated from seedlings produced in multi-cell trays. Taking into account the two-yearold plants, no significant impact of the plantation establishment method on flower yield was found. On average, total yields of flowers varied from $17.2{\mathrm{dt} \times \mathrm{ha}^{-1}}$ in the first year of vegetation to $27.8 \mathrm{dt} \times \mathrm{ha}^{-1}$ in the case of the two-year-old plants.

Key words: marshmallow, Althaea officinalis L., plantation establishment method, flower yield

\section{INTRODUCTION}

Marshmallow Althaea officinalis L. is a valuable medicinal plant belonging to the Malvaceae family. The roots of the plant are the most frequently used pharmaceutical raw material, but the flowers are also significant, particularly in folk medicine. Pale pink, five-petalled flowers, up to $5 \mathrm{~cm}$ in diameter, grow individually or in bunches from the corners of the leaves in the upper part of the stalks. The plant flowers in July and August, but the flowering stage often extends until September. A single flower ceases to blossom quite early, after 3-4 days. That is why flowers in blossom occur next to those that have already ceased. For medicinal purposes, flowers are collected successively as they bloom. Proven medicinal properties are primarily attributed to the mucilage which is present in the flowers and roots and has antitussive, softening and coating effects ( $\mathrm{Hojden}$,
1996; K o złowski et al. 1989; Strzelecka and $\mathrm{K}$ a $\mathrm{m}$ iń s k i, 2000). Besides the mucilage, the flowers contain flavonoids, the most important of which is tiliroside, a compound with a proven anti-inflammatory effect (G u d e j, 1990). Marshmallow preparations belong to the group of agents used for the treatment of respiratory tract infections, stomatitis, pharyngitis and esophagitis as well as digestive tract disorders and metabolism disorders (B u c h w a ld and S z c z y g l e w s k a, 1999; K o zło w s k i, 1995).

In the literature output, research concentrates on yields of roots and there is a lack of information concerning the flowers. The aim of this study was to determine the effect of the plantation establishment method on flowering dynamics and flower yield in the first and the second year of marshmallow vegetation.

\section{MATERIALS AND METHODS}

The results of the study based on a field experiment done in the years 2002-2004 in Zamość on brown soil of loess origin. The soil was characterized by a medium humus and magnesium content, very high phosphorus and potassium content, and it was neutral in reaction. Mineral fertilization was applied in the following doses $\left(\mathrm{kg} \times \mathrm{ha}^{-1}\right): 70 \mathrm{~N}, 25 \mathrm{P}, 90 \mathrm{~K}$. The following methods of plantation establishment were compared: 1) direct sowing in the field (control object); 2) direct sowing in the field with cover of polypropylene sheet; 3) planting seedlings obtained in a heated plastic house (tunnel); 4) planting seedlings produced in multi-cell propagation trays (also in a plastic house). The experiment was set in a scheme of random blocks in four replications on plots of $20 \mathrm{~m}^{2}$ each. Every year the plots were divided into 2 halves, one was used for one-year-old plants, while the other was assigned for two-year-old plants. In order to obtain seedlings (in both objects) seeds were sown in the middle of March, on a peat substrate. In the field seeds were sown in mid-April. Directly after the sowing, 
the designated plots were covered with polypropylene sheet, which was removed when the plants reached the height of about $15 \mathrm{~cm}$. The seedlings were transplanted to the field at the beginning of May. The same spacing of plants, $50 \times 40 \mathrm{~cm}$, was used in all the objects.

During the vegetation period, observations of flowering were conducted. As the plants were coming into blossom, the flowers were colected at 2-3 day intervals (from 10 plants on each plot). The fresh weight of the flowers was determined and the air dry weight was recorded after 2 weeks of drying (in natural conditions). The yield achieved was calculated per hectare. Furthemore, the number of flowers produced by one plant was determined. The results were statistically analyzed with Tuckey's method and the smallest significant differences were calculated.

\section{RESULTS}

The weather conditions during the research determined the course of marshmallow flowering, especially in the first year of vegetation (Tab. 1). Warm and humid weather in May and June in the years 2002 and 2003 was conducive to the development of the plants, and the full flowering stage was observed in the second half of July (except for the control object). The weather in year 2004 was less favourable. A considerable deficiency of rainfall in late April and the $1^{\text {st }}$ half of May impeded the emergence and prolonged the seedling stage of plants, whereas low precipitation in June and July (1st and 2nd decade) delayed the flowering stage, as compared to the other years.

Flowering of the one-year-old plants depended on the method of plantation establishment. It was found

Table 1

Mean decade air temperature and total rainfall in 2002-2004.

(data from Zamość Meteorological Station)

\begin{tabular}{|c|c|c|c|c|c|c|c|}
\hline \multirow{2}{*}{ Month } & \multirow{2}{*}{ Decade } & \multicolumn{3}{|c|}{ Mean air temperature $\left({ }^{\circ} \mathrm{C}\right)$} & \multicolumn{3}{|c|}{ Sum of rainfall (mm) } \\
\hline & & 2002 & 2003 & 2004 & 2002 & 2003 & 2004 \\
\hline \multirow{3}{*}{ April } & I & 4.7 & 2.3 & 6.3 & 6.0 & 5.0 & 31.9 \\
\hline & II & 11.2 & 8.5 & 11.1 & 8.0 & 18.8 & 10.9 \\
\hline & III & 12.6 & 12.5 & 11.5 & 20.8 & 12.9 & 3.5 \\
\hline \multirow{3}{*}{ May } & I & 17.9 & 17.6 & 15.2 & 0.0 & 24.9 & 12.1 \\
\hline & II & 16.5 & 15.3 & 12.7 & 16.9 & 66.7 & 4.9 \\
\hline & III & 18.4 & 18.3 & 12.7 & 98.9 & 19.8 & 33.1 \\
\hline \multirow{3}{*}{ June } & I & 15.8 & 19.3 & 18.1 & 58.7 & 22.0 & 4.7 \\
\hline & II & 19.5 & 18.1 & 18.1 & 27.9 & 6.0 & 10.5 \\
\hline & III & 19.6 & 17.1 & 18.0 & 59.7 & 17.0 & 19.7 \\
\hline \multirow{3}{*}{ July } & I & 21.4 & 18.4 & 19.3 & 22.9 & 106.5 & 15.6 \\
\hline & II & 23.4 & 19.2 & 18.7 & 108.7 & 8.0 & 13.4 \\
\hline & III & 20.3 & 23.8 & 20.2 & 4.0 & 30.2 & 116.0 \\
\hline \multirow{3}{*}{ August } & I & 21.4 & 27.2 & 19.3 & 9.5 & 0.0 & 29.2 \\
\hline & II & 20.2 & 20.2 & 21.1 & 5.0 & 5.0 & 12.6 \\
\hline & III & 19.9 & 14.6 & 18.7 & 0.0 & 5.8 & 30.1 \\
\hline \multirow{3}{*}{ September } & I & 20.0 & 10.4 & 15.6 & 2.7 & 0.0 & 19.5 \\
\hline & II & 10.5 & 10.7 & 15.6 & 34.8 & 0.0 & 1.2 \\
\hline & III & 9.7 & 14.8 & 11.4 & 13.8 & 0.8 & 15.6 \\
\hline
\end{tabular}


Table 2

Numer of days to the date of reaching full blooming stage.

\begin{tabular}{|c|c|c|c|c|c|c|c|}
\hline \multirow{2}{*}{ Object } & \multicolumn{4}{|c|}{ One-year-old plants } & \multicolumn{3}{|c|}{ Two-year-old plants } \\
\hline & 2002 & 2003 & 2004 & Mean & 2003 & 2004 & Mean \\
\hline $\begin{array}{l}\text { Seeds sown in the field } \\
\text { (control) }\end{array}$ & 109 & 111 & 123 & 114.3 & 87 & 89 & 88.0 \\
\hline $\begin{array}{l}\text { Seeds sown in the field } \\
+ \text { cover of polypropylene }\end{array}$ & 106 & 103 & 120 & 109.7 & 87 & 89 & 88.0 \\
\hline $\begin{array}{l}\text { Seedlings from } \\
\text { plastic house }\end{array}$ & 80 & 81 & 92 & 84.3 & 88 & 89 & 88.5 \\
\hline $\begin{array}{l}\text { Seedlings produced in } \\
\text { multiplates }\end{array}$ & 81 & 79 & 94 & 84.7 & 88 & 89 & 88.5 \\
\hline
\end{tabular}

that marshmallow grown from seedlings achieved the blooming stage much earlier than the plants from direct sowing in the field. Covering the plots with polypropylene shortened however the period between seed sowing and the time of full flowering, on average by 3 days in the years 2002 and 2004 and by 8 days in 2003 (Tab. 2).

In the second year of vegetation, flowering was observed much earlier in comparison to one-year-old plants, and the full flowering stage occurred at the beginning and mid of July, in 2003 and 2004 respectively. It was found that the plantation establishment method in the particular years did not influence the length of the period between the beginning of vegetation in spring and the flowering stage. Although in 2004 the full flowering stage was recorded on average 11-12 days later as compared to the previous year, it was caused by the delayed beginning of the spring vegetation of plants.
The method of plantation establishment modified the yield of marshmallow flowers. In the first year of vegetation at the beginning of the flowering stage, a small yield was obtained, but it was gradually higher over time (Figs 1-3). In the plots where seedlings were planted, the plants produced much more flowers in this period. The above trend in the years 2002 and 2003 was observed until the end of July and the middle of August, respectively, whereas in the last year of research, throughout the entire flowering stage. When analysing the flower yield during the successive collections, it was found that the most intensive flowering of marshmalow cultivated from direct sowing occured in early August in 2002 and in the second half of this month in the other years. The plants cultivated from seedlings produced the highest yield of flowers in the second half of July and early August in the years 2002 and 2003, and in the second half of August in the last year of research.

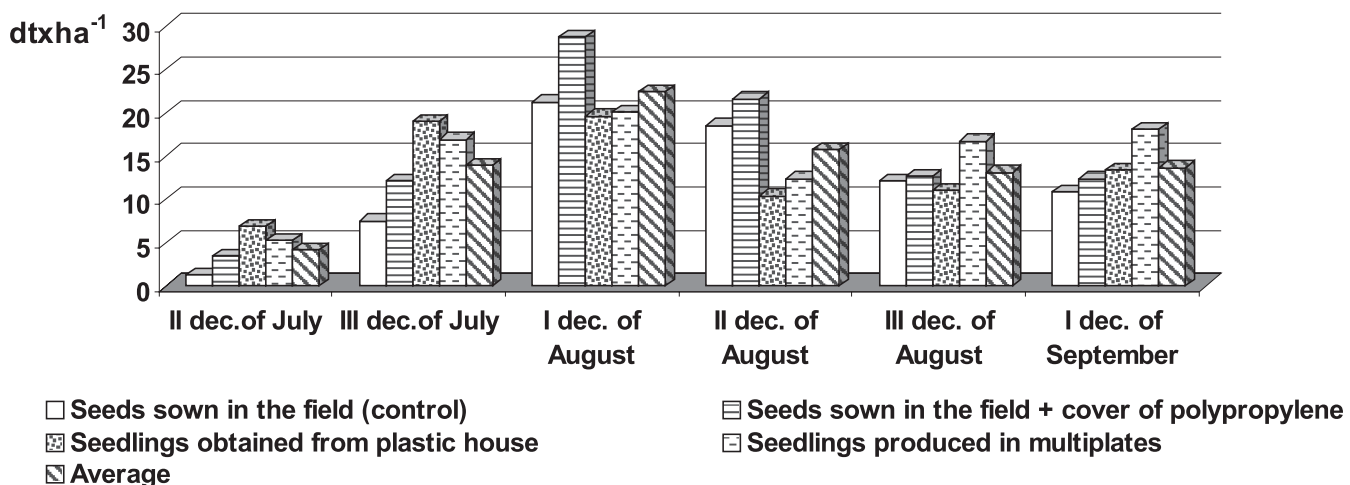

Fig. 1. Flower yield dynamic of one-year-old marshmallow plants (2002). 


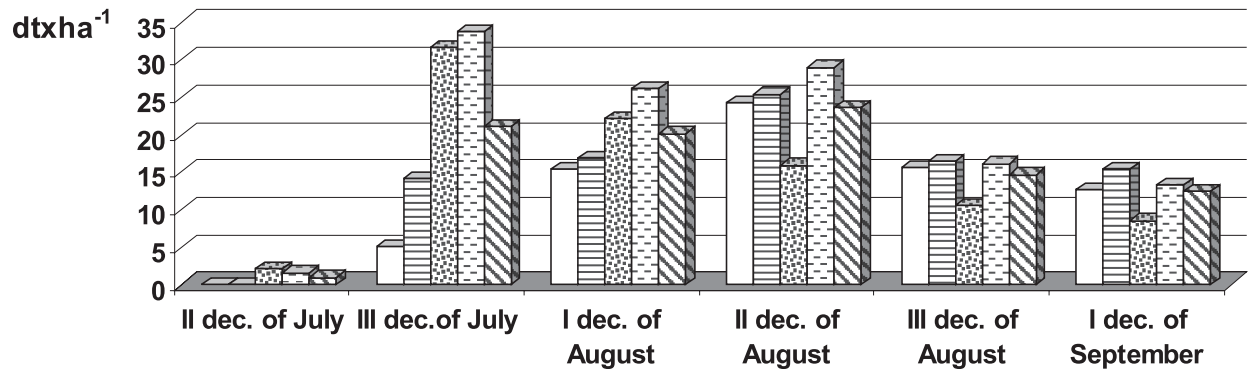

$\square$ Seeds sown in the field (control) 图 Seedlings obtained from plastic house \$ Average

Seeds sown in the field + cover of polypropylene $\square$ Seedlings produced in multiplates

Fig. 2. Flower yield dynamic of one-year-old marshmallow plants (2003).

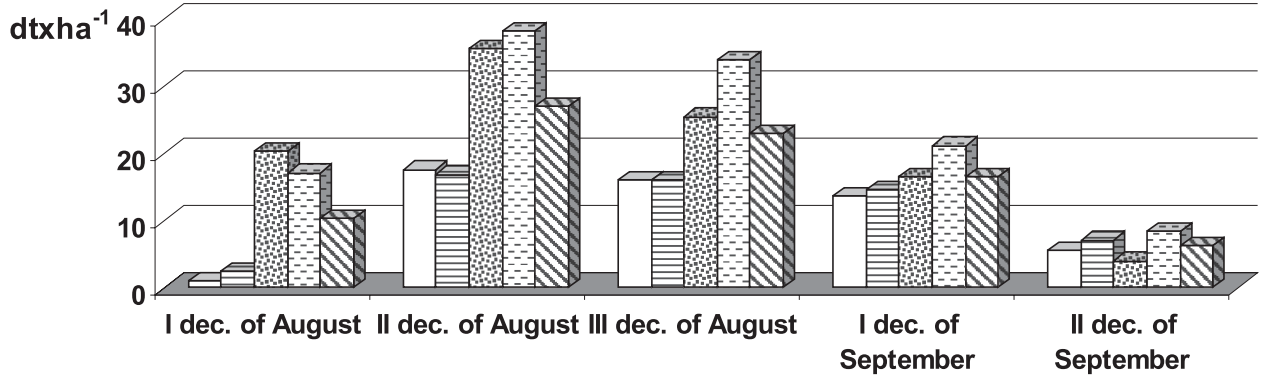

$\square$ Seeds sown in the field (control) 图 Seedlings obtained from plastic house

$\boxminus$ Seeds sown in the field + cover of polypropylene \$Average

$\checkmark$ Seedlings produced in multiplates

Fig. 3. Flower yield dynamic of one-year-old marshmallow plants (2004).

Table 3

Total yield of fresh and air dry mass of flowers and number of flowers per plant.

\begin{tabular}{|c|c|c|c|c|c|c|}
\hline \multirow[b]{2}{*}{ Object } & \multicolumn{3}{|c|}{$\begin{array}{l}\text { One-year-old plants } \\
\text { (average in the years } 2002-2004 \text { ) }\end{array}$} & \multicolumn{3}{|c|}{$\begin{array}{l}\text { Two-year-plants } \\
\text { (average in the years } 2003-2004 \text { ) }\end{array}$} \\
\hline & $\begin{array}{l}\text { Fresh mass } \\
\text { of flowers } \\
d \mathrm{dt} \times \mathrm{ha}^{-1}\end{array}$ & $\begin{array}{c}\text { Air dry mass } \\
\text { of flowers } \\
\text { dt } \times \mathrm{ha}^{-1}\end{array}$ & $\begin{array}{l}\text { Number of } \\
\text { flowers per } \\
\text { plant }\end{array}$ & $\begin{array}{c}\text { Fresh mass } \\
\text { of flowers } \\
d \mathrm{dt} \times \mathrm{ha}^{-1}\end{array}$ & $\begin{array}{c}\text { Air dry mass } \\
\text { of flowers } \\
\text { dt } \times h^{-1}\end{array}$ & $\begin{array}{c}\text { Number of } \\
\text { flowers per } \\
\text { plant }\end{array}$ \\
\hline $\begin{array}{l}\text { Seeds sown in the field } \\
\text { (control) }\end{array}$ & 66.2 & 13.0 & 596 & 124.0 & 26.5 & 1116 \\
\hline $\begin{array}{l}\text { Seeds sown in the } \\
\text { field }+ \text { cover of } \\
\text { polypropylene }\end{array}$ & 78.7 & 15.4 & 648 & 127.0 & 29.6 & 1161 \\
\hline $\begin{array}{c}\text { Seedlings from plastic } \\
\text { house }\end{array}$ & 91.0 & 18.4 & 843 & 119.5 & 27.7 & 1092 \\
\hline $\begin{array}{l}\text { Seedlings produced in } \\
\text { multiplates }\end{array}$ & 109.5 & 22.2 & 986 & 122.6 & 27.5 & 1132 \\
\hline Average & 86.4 & 17.2 & 768 & 123.3 & 27.8 & 1125 \\
\hline $\mathrm{LSD}_{0,05}$ & 9.7 & 2.1 & 99 & ns. & ns. & ns. \\
\hline
\end{tabular}




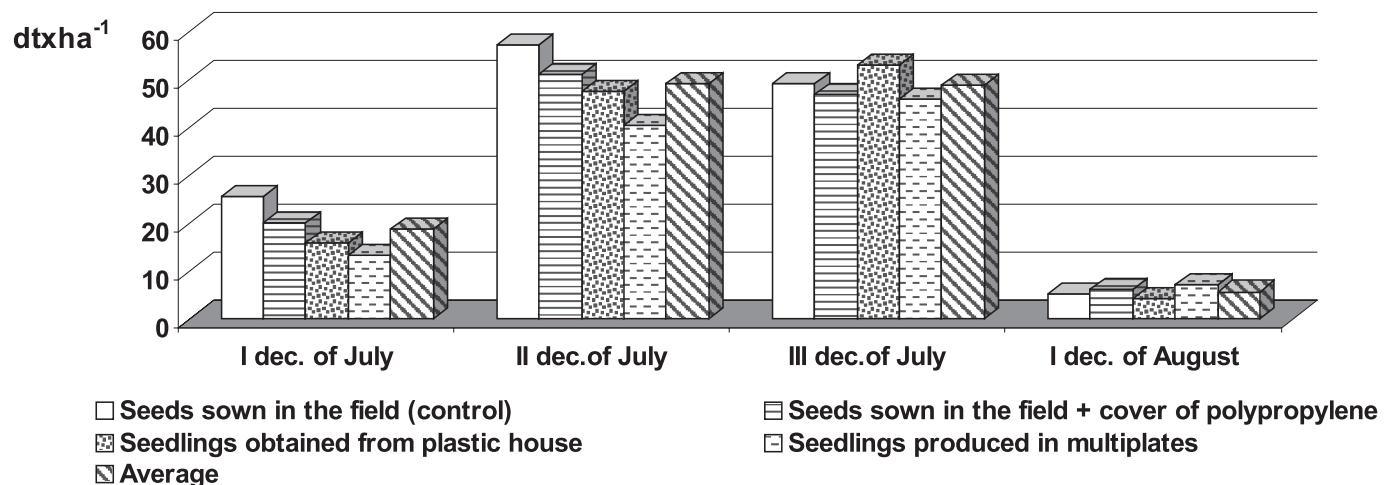

Fig. 4. Flower yield dynamics of two-year-old marshmallow plants (2003).

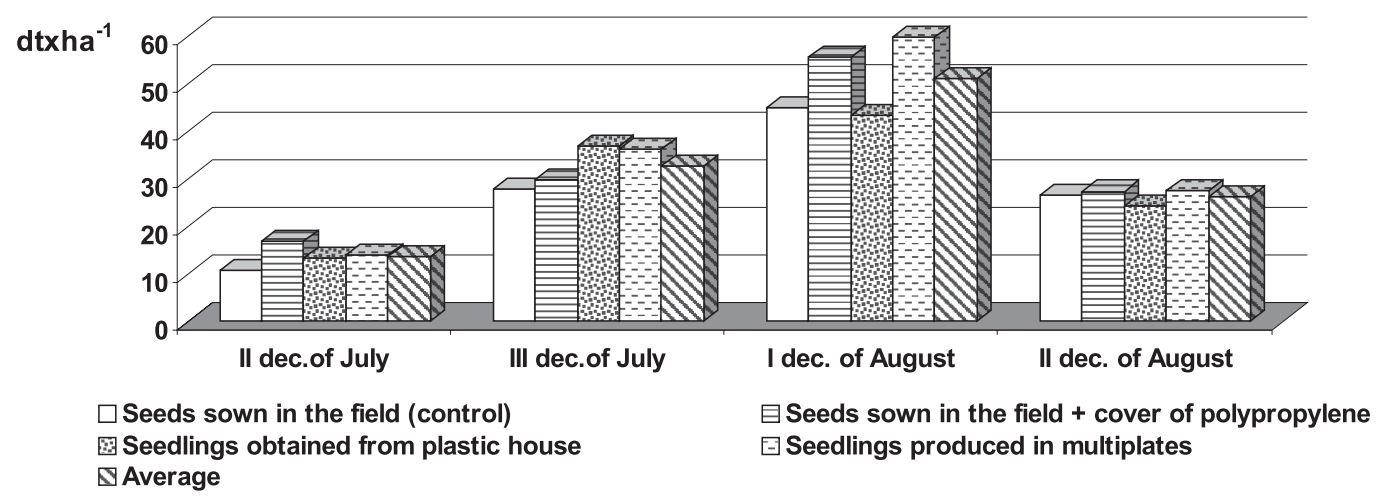

Fig. 5. Flower yield dynamic of two-year-old marshmallow plants (2004).

The total yields of fresh and air dry mass of flowers in the first year of vegetation amounted to 86.4 $\mathrm{dt} \times \mathrm{ha}^{-1}$ and $17.2 \mathrm{dt} \times \mathrm{ha}^{-1}$, respectively. Statistically significant differences in the yield were among all the experimental objects (Tab. 4). Establishing the plantation from seedlings produced in multiplates was the best method in terms of flower generation. The plants from this object produced the largest number of flowers, resulting in the highest yield of fresh and air dry mass of flowers. Significantly lower values of these traits were achieved when seedlings were produced in a plastic tunnel, whereas direct sowing proved to be the least effective method.

The collection of flowers in the plantation with two-year-old plants began about two weeks earlier than in the first year of vegetation (Figs 4-5). The greatest number of flowers was obtained in the second half of July in 2003 and at the beginning of August in 2004. On average, the yields of fresh and air dry matter of flowers were higher, as compared to one-year-old plants (by $48 \%$ and $62 \%$, respectively), but the method of plantation establishment had no significant influence on the yield and number of marshmallow flowers in the second year of vegetation.

\section{DISCUSSION}

In the available scientific literature there is lack of information concerning the quantity of marshmallow flower yield. Flowers are only mentioned as an additional product obtained in the production of roots. Although flowers and roots show similar medicinal properties, the former are of secondary importance and currently there is small demand for them as raw material. In this experiment, the yield of air dry flowers of one-year-old plants was much smaller than two-year-old (on average $17.2 \mathrm{dt} \times \mathrm{ha}^{-1}$ and $27.8 \mathrm{dt} \times \mathrm{ha}^{-1}$, respectively). As concerns methods of plantation establishment, significant differences (in terms of seedling propagation) only in the first year of vegetation were recorded.

In Poland, a growing interest in the production of herbal plant seedlings in multi-cell propagation trays has been observed (A n d r u z z z a k and Wi śn i e w ski, 2007; Sugier, 2004; Kołodziej and Naj$\mathrm{d} a, 2007)$. According to B erbeć (2002) as well as Zaorski and Kołodziej (2000), this system of seedling production could be an important factor of yields and raw material quality increase. Such seedlings have a well-developed root system that ensures a $100 \%$ rooting rate after planting in the field as well as a shorter 
period of adaptation to the new environment. Research conducted so far has indicated that marshmallow cultivated from seedlings produced in multiplates was characterized by faster growth and development rates and generated higher root weight than plants cultivated from seedlings obtained in a plastic house (A n d r u s z c z a k and Wiśniewski, 2007). This experiment proves that using multi-cell trays for seedling production exerted a positive effect also on the yield and the number of flowers in the first year of plant vegetation.

Using the polypropylene sheet (after seed sowing) was found to have a positive influence on the flowering and flower yield. According to literature, favourable conditions for the growth and development of plants are ensured by the peculiar microclimate under the polypropylene sheet, particularly higher air and soil temperature and higher humidity as compared to the field with no cover (C ěrne, 1994; S i w e k, 1999). Covering the plots with polypropylene sheet in the first year of plant vegetation resulted in earlier flowering ( 3 to 8 days than in the control object), and a significantly greater number and weight of flowers. In the second year of vegetation, however, the influence of this cultivation method on the traits examined was not observed.

\section{CONCLUSIONS}

1. Two-year-old marshmallow plants reached the full flowering stage sooner and showed a higher yield potential, as compared to plants in the first year of vegetation.

2. The compared methods of plantation establishment significantly modified yields and number of flowers only in the case of one-year-old plants.

3 . In the first year of vegetation, the best results were achieved when plants were grown from seedlings produced in multi-cell propagation trays. Plants cultivated in this manner produced the highest yield of fresh and air dry matter of flowers and were characterized by the greatest number of flowers.

4. Using the cover of polypropylene sheet after the seeds were sown accelerated the full flowering stage and significantly increased the yield of flowers, as compared to those not covered.

\section{REFERENCES}

Andruszczak S., Wiśniewski J., 2007. Growth and development of marshmallow (Althaea officinalis L.) depending on the method of plantation establishment. Herba Pol. 3: 63-69.

Berbeć S., 2002. A question of present-day cultivation of herbs. Wiad. Ziel. 8/9: 10-11.

Buchwald W., Szczyglewska D., 1999. Marshmallow a source of mucilaginous substances. Wiad. Ziel. 2: 8-9.

Cěrne M., 1994. Different agrotextiles for direct covering of pickling cucumbers. Acta Hort. 371: 247-252.
Gudej J., 1990. Determination of flavonoids in leaves, flowers and roots of Althaea officinalis L. Farm. Pol. 5/6: 153155.

Hojden B., 1996. Medicinal plants - a rich source of mucilage. Wiad. Ziel. 7/8: 14-16.

Kołodziej B., Najda A., 2007. Plantation establishment methods in cultivation of chosen medicinal plants. Herba Pol. 3: $268-272$.

Kozłowski J., 1995. Plants containing mucilage and pectins and their value in phytotherapy. Wiad. Ziel. 6: 8-9.

Kozłowski J., Szczyglewska D., Formanowiczowa H., 1989. Biology of germination of medicinal plants seeds. XIV. Seeds of species from Malvaceae family: marsh mallow (Althaea officinalis L.) and mallow (Malva silvestris L.). Herba Pol. 2/3: 99-107.

Siwek P., 1999. Pro-ecological aspects of plastic covers application in the early cucumber cultivation. Zesz. Probl. Post. Nauk Rol. 466: 513-527.

Strzelecka H., Kowalski J., 2000. Encyclopaedia of herbcultivation and phytotherapy. PWN, Warszawa.

Sugier D., 2004. The effect of row arrangment and plantation establishment on the yielding of common dandelion ( $\mathrm{Ta}$ raxacum officinale Web.). Ann. UMCS, Sect. E, 59 (2): 535-541.

Zaorski T., Kołodziej B., 2000. Technical and technological improvements in preparation and transplanting seedlings of herbal plants. Wiad. Ziel. 5: 20-21.

\section{Wpływ sposobu zakładania plantacji na plon kwiatów prawoślazu lekarskiego (Althaea officinalis L.)}

\section{Streszczenie}

Doświadczenie polowe z jednorocznymi i dwuletnimi roślinami prawoślazu lekarskiego (Althaea oficinalis L.) przeprowadzono w latach 2002-2004 w Zamościu na glebie brunatnej pochodzenia lessowego. Porównywano następujące sposoby zakładania plantacji: 1) wysiew nasion wprost do gruntu (kontrola); 2) wysiew nasion wprost do gruntu z przykryciem agrowłókniną; 3) wysadzanie rozsady uzyskanej w tunelu foliowym; 4) wysadzanie rozsady wyprodukowanej w tacach wielokomórkowych w tunelu foliowym.

Wykazano, że w przypadku roślin jednorocznych, wszystkie sposoby zakładania plantacji (w porównaniu z obiektem kontrolnym) istotnie zwiększyły plony i liczbę kwiatów prawoślazu lekarskiego, przy czym najlepsze rezultaty uzyskano wysadzając rozsadę wyprodukowaną w tacach wielokomórkowych. Analizując plony kwiatów zebranych z roślin dwuletnich nie stwierdzono istotnego wpływu sposobu zakładania plantacji na badane cechy. Plony powietrznie suchej masy kwiatów roślin jednorocznych były niższe (średnio wynosiły 17,2 dt $\times h^{-1}$ ) niż dwuletnich (średni plon z wszystkich obiektów 27,8 dt $\times \mathrm{ha}^{-1}$ ). 